\title{
Possessing Love's Reasons
}

\author{
Or Why a Rationalist Lover Can \\ Have a Normal Romantic Life
}

TING CHO LAU

King's College, PA

The rationalist lover accepts that whom she ought to love is whom she has most reason to love. She also accepts that the qualities of a person are reasons to love them. This seems to suggest that if the rationalist lover encounters someone with better qualities than her beloved, then she is rationally required to trade up. In this paper, I argue that this need not be the case and the rationalist lover can have just about as normal if not a better romantic life than anyone could hope for. This is because we often do possess most reason to love our beloveds. To see why this is so, we have to think more carefully about (i) how we come to possess reasons for love and (ii) the higher-order reasons that govern whether we should seek or refrain from possessing said reasons. Reflection on these issues leads to what I call the Possession-Commitment Account of Love's Reasons. I use this account to address additional worries for love rationalism and highlight how being rational about love can potentially get us out of romantic messes. I conclude that if being a rationalist about love is plausible after all, then we have reason to hope that being rational about other areas of our practical lives is plausible as well.

\footnotetext{
Cuppose you are what I call a rationalist lover. For you, figuring out what you ought to do or how you ought to feel is a matter of appropriately responding to what your reasons most favor. You also think that the positive qualities of a person are weighty reasons for romantic love. ${ }^{1}$ Each claim is plausible on
}

1. Though I focus on romantic love in the paper, similar arguments can apply for other forms of love that tend to be exclusive and subject to our choice (e.g., friendship). The scope of this paper

Contact: Ting Cho Lau <tingcho.lau@villanova.edu> 
its own, but things get tricky when you combine them. Question: can you lead a normal romantic life?

At first glance, if you are a committed rationalist lover, your romantic life will be a mess. You will feel constant pressure to trade up whenever you meet or are even aware of someone with seemingly better qualities than your present beloved. Intuitively, we not only do not, but we should not live our romantic lives this way. While people's qualities provide us with reasons to love them, most of us think that it is perfectly rational for us to refuse to trade up whenever we meet someone with seemingly better qualities. It also seems perfectly rational for us to remain in love with our beloveds even if they end up losing some of their loveable qualities.

In this paper, I will argue that despite appearances, a rationalist lover can have about as normal (if not a better) romantic life than anybody else can hope to have. Granted, the rationalist I am envisioning will have to accept that they ought to trade up in some cases. Even so, we will see that trading up might be the plausible thing to do in those cases after all.

Before proceeding, it is important to state the scope of the present discussion and how it aims to bring a novel contribution to the vast and expanding literature on love. The present discussion is not an attempt to determine whether love rationalism or non/anti-rationalism is the better position. ${ }^{2}$ Instead, the focus is squarely on showing why a rationalist lover-that is, someone who accepts the plausible claims that (i) we ought to do (feel) what we have most reason to do (feel) and (ii) the qualities of a beloved are weighty reasons to romantically love them-holds a sensible position that does not preclude a normal romantic life. As for novelty, my case will not rely on contentious accounts of reasons (e.g., appealing to distinctive second-personal reasons, haecceistic reasons, noninsistent reasons, etc.). We can accept that there are just ordinary reasons that figure in ordinary weighing explanations. Instead, my defense of the rationalist lover appeals to a general thesis about how we come to possess reasons for any attitude or action that also neatly explains why first-personal experience and close attention to someone plays a key role in possessing reasons for romantic love in particular. Lastly, by considering the processes through which we possess reasons for love, we'll also see how rationalist lovers are not just passive responders to reasons but also agents that play an active role in determining what reasons they possess and thereby whom they ought to love.

will not cover forms of love that are not exclusive or not subject to our choice (e.g., parental love, agape, etc.).

2. A commentator notes that there is disagreement on how the distinction should even be drawn (e.g., in terms of whether there are fittingness-based reasons for love, whether there are non-quality-based reasons for love, etc.). I remain neutral on these matters. 
Here is the roadmap for the paper. In section 1, I explicitly state the concern we have for the rationalist position in terms of what I will call the Trading Up Problem. ${ }^{3}$ The problem is generated by three independently plausible claims that combine to cause trouble for the rationalist lover. In section 2, I say a bit more about what I take romantic love to be and propose an account, the Possession-Commitment Account of Love's Reasons (abbreviated as Possession-Commitment Account), that the rationalist lover can use to address the Trading Up Problem. We will also see how the account can be used to address a variety of worries for the rationalist lover. The key is to think more carefully about (i) how we come to possess reasons for love and (ii) the higher-order reasons that govern whether we should seek or refrain from possessing further reasons for love. In section 3, I highlight ways in which my account is inspired by, but differs from, other views in the literature.

\section{A Trading Up Problem for the Rationalist Lover}

To get clear on what the problem for the rationalist lover is supposed to be, consider the following case:

Super Tinder: Amal is a rationalist lover. She met George through Tinder - a dating app commonly used by millennials. Amal has gone on several dates with George who is a great guy. Things are getting serious. One day, while Amal is flipping through her phone, she discovers she was recently given an exclusive upgrade to Super Tinder which produces a highly accurate psychological and physical profile of its users through questionnaires and body scans. Out of curiosity, Amal checks the app and finds out that she has been matched with Nayla. Suppose for all the qualities that Amal is interested in-intelligence, open-heartedness, and moral virtue-Nayla seems superior to George.

Upon discovering Nayla as a romantic possibility, most of us do not think Amal is now rationally required to trade up and love Nayla. Yet, Amal, the ever-rationalist lover, seems committed to trading up if she accepts three independently plausible and fairly popular theses about: (i) how the reasons we have determine what we ought to do or what emotions we ought to have, (ii) how we come to have reasons, and (iii) what counts as a reason for love.

3. A reviewer has pointed out that there are multiple versions of the Trading Up Problem. For the purposes of this paper, we will focus on the version of the problem stated in the next section. 
First, consider:

Choice: If an agent is choosing between two attitudes or actions $\mathrm{A}$ and $\mathrm{B}$, an agent ought not choose $\mathrm{A}$ if she possesses weightier reason to choose $\mathrm{B}$.

Choice states an upshot of the popular view that what we ought to do or what attitude we ought to have just is what our possessed reasons most favor. ${ }^{4}$ This is a non-negotiable for the rationalist lover. ${ }^{5}$ Absent a compelling independent argument, the rationalist lover should accept that Choice applies for love's reasons too.

To be clear, Choice involves a form of perspectivism about what we ought to do (i.e., that what we ought to do depends on our perspectives-e.g., what reasons we have epistemic access to, etc.). Note that on Choice, what actions we ought to do or what attitudes we ought to have are determined by the reasons we possess. ${ }^{6}$ To see why this is important, note that just because some fact is a reason to do something (e.g., lottery fact - the winning ticket numbers to a million dollar lottery will be 5, 9, 32, and 16) does not entail that I thereby possess it in a way that would determine what I ought to do (e.g., buy a ticket and write those numbers down). If I have no way of knowing this fact, I intuitively fail to possess it as a reason to do anything. It cannot play an action-guiding role in determining what I ought to do. At the very least, I must bear some epistemic relation to the fact in order for it to play an action-guiding role.

This leads us to our second thesis:

Possession as Knowledge: What it is for agent $A$ to possess reason $\mathrm{R}$ to have attitude $\varphi$ provided by fact $\mathrm{F}$ is for $\mathrm{A}$ to know $\mathrm{F}$ and for $\mathrm{R}$ to be a reason to $\varphi .7$

What conditions must be met for me to possess some fact as a reason to do something (i.e., a fact that can play a role in determining what I ought to do or what attitudes I ought to have)? One candidate common in the literature (and one that we will reconsider shortly) is simply knowing said fact. Continuing with lottery fact, if I could somehow come to know it, having this knowledge is sufficient for me to possess said fact as a reason to buy a lottery ticket and write certain numbers on it.

4. See Parfit (2011), Portmore (2011), and Robertson (2008) for examples. Though there might be independent arguments to reject Choice, I will bracket them for the purposes of this paper.

5. I am not claiming that all philosophers who think that there are reasons for love must accept Choice. For example, Jollimore (2011) rejects choice.

6. See Lord (2018b) for extensive discussion and development of this view. The argument presented here is a version of the Argument from Action Guidance which is treated extensively in Fox (2019).

7. See Kiesewetter (2018), Parfit (2011) and Schroeder (2008). 
This leads us to our third and final thesis. If knowledge of some fact is sufficient for possessing it as a reason, then what would we have to know about a person that would lead us to possess reasons to love them? Consider the following:

Quality View: The positive qualities of a beloved are weighty reasons to love them. ${ }^{8}$

Though some philosophers are suspicious that there are reasons for love precisely because they are worried about problems for love rationalism, many philosophers also think that the positive qualities of a person are reasons to love them because they are facts that count in favor of doing so. For example, a person's patience, open-mindedness, generosity, beauty, humor, or gruffness can all be reasons to love them. ${ }^{9}$

Each thesis is independently plausible. But when taken together, they place rational pressure on Amal to trade up. If Amal, through Super Tinder, knows that Nayla has better qualities than George, barring other considerations, she possesses weightier reason to love Nayla over George. On pain of violating Choice, she ought to trade up. But intuitively, we do not think she is under rational pressure to do so. Call this the Trading Up Problem for love rationalism. The rationalist lover who wants to preserve common sense will have to reject one of the above theses, defend additional theses, or do both.

While a common strategy for resolving the Trading Up Problem is to make love's reasons exempt from the weighing explanations implicit in Choice, I propose that the rationalist lover think more carefully about Possession as Knowledge and Quality View. ${ }^{10}$ In particular, the rationalist lover should think more carefully about how we generally come to possess reasons, to what extent we have control over this process, and what reasons can govern this process.

Here is a preview. In defending the Possession-Commitment Account of Love's Reasons, I will argue that (i) first-personal experience of a person's qualities or at least prolonged interactions with them (not just propositional knowledge of them) plays a vital role in possessing said qualities as reasons for love, (ii) that whether we engage in these prolonged first-personal experiences or interactions is subject to our control in virtue of the commitments we make or don't make, and (iii) there are non-quality-based reasons to maintain one's reasons in favor of loving one's beloved. If so, then love rationalism and actual romantic

8. For examples of the quality view, see Brogaard (2014), Delaney (1996), Naar (2017), Howard (2019), Jollimore (2011), and Solomon (2006).

9. See Zangwill (2013) and Han (in press) who deny that there are reasons for love.

10. One way of doing this that is common in the literature is to argue that love's qualities are reasons that cannot generate deontic requirements. They are non-insistent, enticing, or merely justifying reasons. See Jollimore (2011) as an example. I consider reasons to reject this approach in Section 3.2. 
practice can be compatible because we often do possess most reason to love the people we do in virtue of (i)-(iii).

\section{The Possession-Commitment Account of Love's Reasons}

\subsection{Romantic Love}

Before presenting the Possession-Commitment Account, let me say a bit more about romantic love. Romantic love is admittedly complex. There is significant debate as to whether it is an emotion, can involve a limited bestowal of value, is a kind of moral attitude, is partially socially constructed, or can be directed towards multiple people. ${ }^{11}$ Though officially neutral on these matters, I will claim that romantic love is characterized by a set of symptomatic dispositions to act, feel, and reason that are relatively exclusive (though not necessarily monogamous) and distinct from dispositions that constitute other forms of love. Here is a rough initial characterization: ${ }^{12}$

Romantic Love: Romantic love, at least in part, consists in dispositions to act, feel, and reason in ways that are (a) responsive to the beloved's qualities, (b) distinctive of romantic engagement, and (c) relatively exclusive in scope.

Examples include dispositions to favor the beloved's interests in practical deliberation, to admire and enjoy their intellectual, moral, and physical qualities, and to reason in ways that would present their qualities in a positive light both to yourself and to others. ${ }^{13}$

While there are additional complexities, the above characterization is both ecumenical and substantive enough for us to raise the Trading Up Problem for any reasons-based account of love that finds Choice, Possession as Knowledge, and the Quality View plausible. If romantic love consists, at least in part, in the dispositions just discussed, we must ask: Why is someone not rationally required to trade up by developing these dispositions towards a person with better qualities than one's existing beloved ${ }^{14}$

11. For discussion of love as an attitude responsive to qualities, see Brogaard (2014) and Delaney (1996). For discussion of love as a form of commitment that bestows value, see Frankfurt (2004). For discussion of love as a moral emotion, see Velleman (1999). For discussion of love's ability to justify partiality, see Setiya (2014). For a discussion of ethical polyamory, see Jenkins (2017).

12. I am inspired by Martin (2014) who provides an account of hope as a kind of syndrome. Also see de Sousa (2015).

13. For detailed discussion see Jollimore (2011). I will discuss his account in Section 3.

14. While I sometimes speak of reasons for love in a way that suggests that loving is a type of action, I am not committed to the idea that love is an action. Given my characterization of romantic 


\subsection{The Possession-Commitment Account}

Instead of making romantic love exempt from Choice, I propose that we critically examine Quality View and Possession as Knowledge. My proposal for how the rationalist lover can address the Trading Up Problem is simple. The rationalist lover has no in-principle way of ruling out cases that would require her to trade up. Nonetheless, she can point out that we usually do possess most reason to love whom we do in virtue of how we come to possess reasons and the active role we play in determining what reasons we possess. These claims constitute the core of the Possession-Commitment Account. As for the cases in which the rationalist lover does possess most reason to trade up, I will argue that a rational requirement to trade up is plausible after all.

Here are the three theses that comprise the Possession-Commitment Account:

Possession: What it is for agent $\mathrm{A}$ to possess reason $\mathrm{R}$ to $\varphi$ provided by fact $\mathrm{F}$ is for $\mathrm{A}$ to be in a position to manifest knowledge about how to use $\mathrm{R}$ to $\varphi .{ }^{15}$

Attention: Which qualities of a person we possess as reasons to love them depends on whether and how we attend to those qualities.

Complexity and Commitment: Facts that are not about the qualities of a person (e.g., the value of your relationship, shared history, children, etc.) can still be weighty reasons for love though they need not be fitbased reasons for love. ${ }^{16}$

\subsubsection{Possession}

To motivate Possession and to see why it is part of a systematic rather than ad hoc response available to the rationalist lover, let us recall Possession as Knowledge. Possession as Knowledge tells us that all it takes to possess a reason to $\varphi$ is to (a) know some fact and (b) for that fact to be a reason to $\varphi$. As noted, Possession as Knowledge makes plausible predictions about lottery fact. My coming to

love as a set of dispositions to act and feel, so long as there are reasons to develop these dispositions, I take said reasons to be reasons for love. Note that other philosophers such as Jollimore and Howard treat the Trading Up Problem seriously even though they do not claim that love is an action. One potential worry is that love is an evaluative attitude but there are no reasons for attitudes. See Maguire (2018) for discussion and Faraci (2020) for a rebuttal.

15. The formulation is from Lord (2018b: 124). As noted earlier, I assume a perspectivist view on which claims about rationality and what an agent ought to do are a function of her possessed reasons. I consider the prospects for my view if we drop this assumption in the last section.

16. This is defended in Howard (2019). 
know the winning lottery numbers in advance seems sufficient for me to possess the lottery fact as a reason to buy a ticket.

Though plausible in simple cases, rationalist lovers should note that Possession as Knowledge cannot serve as a general account of how we come to possess facts as reasons that then determine what we ought to do. It predicts that we possess reasons that we intuitively do not possess - reasons that intuitively cannot play an action-guiding role that determines what it is rational for us to do. Consider the following example from Lord:

Fish: Lois just ordered fish from her favorite seafood restaurant. Right before she digs in, the waiter comes out to inform her that the fish contains salmonella. Lois has the unfortunate belief that salmonella is one of the many bacteria found in food that is harmless to humans. And, indeed, this belief is rational. A renowned food scientist told her so. So, she goes ahead and forms an intention to eat the fish and eats the fish. (Lord 2018b: 98)

The fact that the fish has salmonella is (in most cases) a decisive reason not to order it. If Lois did possess the reason, then it would be irrational for her to order it. But intuitively (though unfortunately), it is not irrational for her to do so. This is because she fails to possess the reason. What Lois is missing is a certain competence or know-how stated by Possession.

Possession: What it is for agent $\mathrm{A}$ to possess reason $\mathrm{R}$ to $\varphi$ provided by fact $\mathrm{F}$ is for $\mathrm{A}$ to be in a position to manifest knowledge about how to use $\mathrm{R}$ to $\varphi$.

Not only must Lois know the salmonella fact in order to possess it, she must also know how to use it as the genuine normative reason it is to avoid ordering the salmon. Lacking this know-how, Lois fails to possess the reason.

If possessing a reason requires knowing how to use it as the genuine normative reason it is, then what other conditions must be met in order for us to possess this know-how with respect to any given reason? For our purpose, we will focus on the upshots of two sufficient conditions. ${ }^{17}$

First, there are a number of cases in which gaining the relevant know-how just involves gaining additional propositional knowledge. In the case of Fish, Lois would possess the relevant know-how if she knew more facts about salmonella (e.g., that it is a bacterium that can make you violently ill). By knowing these

17. To be precise, I do not take these conditions to be enabling conditions for qualities to be reasons for love. These are sufficient conditions for reasons possession. 
additional facts, she gains the ability to use the fact that the fish has salmonella as the decisive normative reason it is to avoid ordering it.

Note that correctly judging that the behavioral and affective dispositions of a person are genuinely moral qualities (and thereby reasons to love them) can take extensive interaction to gain propositional knowledge about that person. For example, we may catch a good person with many moral qualities yelling at an unassuming waiter on a bad day. On the flip side, someone who seems morally upright can turn out to be a brown-nosing moral fraud. To discern whether a potential lover actually has loveable moral qualities in the first place, we will typically need to examine how they act in a variety of contexts to see whether their behaviors exhibit broad patterns of virtue or vice. If so, then possessing a person's character-based qualities as reasons to love them may require us to pay attention to them for a significant amount of time to discern what they are actually like. ${ }^{18}$ Thus, while being in an existing relationship with someone (e.g., friendship, professional relationship, etc.) is not a prerequisite for possessing reasons to love them, it does provide the context by which we are more likely to possess their qualities as said reasons. ${ }^{19}$

Similar things can be said for non-moral character qualities such as humor. ${ }^{20}$ In this case, the ability to love someone for their qualities may involve your having the appropriate background knowledge and affective dispositions to recognize those qualities as qualities rather than defects. Assuming that there are some objective standards for humor, someone may genuinely be humorous. However, we may fail to fully appreciate their humor because we may have a defective background theory of humor, not have the right affective dispositions that would make appreciation possible, or simply fail to pay attention to their humor. Humor is just one example of many qualities whose possession conditions involve extensive theoretical knowledge and proper affective engagement.

Second, there are other cases in which the know-how that is required to possess a fact as a reason for an action or attitude cannot be accounted for in terms of additional propositional knowledge attainable through third-personal means such as testimony. ${ }^{21}$ Sometimes the requisite ability requires first-personal experience. For example, philosophers working on aesthetic testimony have pointed

18. I also suspect that reasons possession comes in degrees. It could be the case that we possess the qualities of many people as reasons to love them but only to a minimal degree. Furthermore, if degrees of possession are directly proportional to weight in deliberation (which is plausible at least with epistemic reasons), then most of these possessed reasons will not be weighty in our deliberation.

19. Though I deny that the existence of a relationship is a requisite enabler for possessing a person's qualities as reasons for love, I do think it is the context in which we are most likely to possess such reasons. See Naar (in press) for this point.

20. I owe the example to Laura Callahan.

21. See chapter 3 and 4 of Lord (2018b) for extensive discussion and defense. Lord defends an anti-intellectualist account of know-how in terms of basic dispositions to respond to normative reasons. 
out that acquaintance with an artwork is required to possess reasons to appreciate it. ${ }^{22}$ Though there are different explanations for why this is so, we can say in broad strokes that experiencing an artwork's qualities for ourselves (e.g., the way its surface reflects light, the dissonance of its resolution, the grittiness of its texture, etc.) puts us in the position to treat said qualities as the genuine normative reasons they are to appreciate them. Testimonial knowledge cannot provide us with these reasons because it cannot make an artwork's specific qualities available to us in this way. ${ }^{23}$

The rationalist lover can point out that possessing love's reasons similarly requires first-personal experience. Note that even if we can love someone without meeting with them in person (e.g., getting tricked into loving a bot or a deceptive online avatar), most would accept that we cannot love solely on the basis of third-personal testimony or definite description of a person. ${ }^{24}$ The rationalist lover can point out that first-personal experience is often required for possessing certain qualities as reasons for love in the same way that first-personal experience is required for possessing aesthetic reasons or reasons for evaluative attitudes in general. Since romantic love, unlike other forms of love, is importantly embodied in specific persons rather than types as its object, we cannot just know that a person has certain qualities generically described. We have to first-personally experience said qualities in order to understand the specific ways in which they are manifested in that person (e.g., their dry wit, their graceful gait, their tender touch, the way their hair parts left of center, their fortitude after a stressful day, etc.). At least for some qualities (e.g., physical qualities and even personality traits), first-personal experience is what allows us to love the beloved for those qualities as the genuine normative reasons they are as opposed to merely recognizing that they belong to a generally loveable type. ${ }^{25}$

22. See Whiting (2015) and Lord (2018a).

23. This paragraph develops points from Lord (2018a). Setiya (2016) also argues that specific facts that are reasons can motivate us more than generic facts that reasons exist. As noted, first-personal experience is what gives us access to these specific facts about a person's qualities. Also see Dillon (1997) who contrasts experiential and intellectual understanding.

24. See Setiya (in press) for discussion.

25. Wodak (in press) has argued that we not only gain reasons for affective responses on the basis of normative testimony but that they can also provide significant justification for said responses. Wodak's strategy is to use contrastive cases in which the relevant testimony comes from highly reliable normative testimony in one case and less reliable normative testimony in another. These contrastive cases are supposed to illustrate that normative testimony can provide comparatively strong justification in some cases. Even if Wodak is correct, this does not diminish the role of first-personal experience in justifying love. First, note that even if reliable testimony can provide comparatively strong justification when compared to unreliable testimony, it may provide comparatively weak justification when contrasted with the justification provided by first-personal experience. Second, it is plausible that in the case of romantic love, your own assessment of a person's qualities as reasons for love will typically (though not always) be more reliable than the testimony that others give. For one, it is plausible that what counts as a reason to love a beloved 


\subsubsection{Attention}

If what I have said about possessing love's reasons is correct, a key upshot is that we have more control over whether we possess love's reasons than critics of love rationalism implicitly assume. Encountering someone prettier or nicer than your beloved does not entail that you thereby possess decisive reason to trade up. To satisfy the possession conditions for certain qualities, we may have to have prolonged interactions with them-interactions we may possess only weak reasons to have. ${ }^{26}$ Case in point, we seldom have reasons to intimately lock eyes with just anyone or spend quality time with them. Problems for the rationalist lover arise only if we assume that (a) possessing the qualities of a person as reasons for love is always easy or (b) that we should always put ourselves in the position to possess the qualities of others as reasons to love them. But neither is the case. Possessing reasons can be difficult. Furthermore, our reasons to attend or not to attend to someone's qualities can often be indecisive. If so, then whom we choose to attend to and thus come to possess reasons to love is importantly up to us at least in the initial stages of romantic love. ${ }^{27}$ Even though rationality is a matter of responding to our possessed reasons, we are not bombarded with possessed reasons in the same way that we are bombarded by background radiation. Possessing reasons in general, not just reasons for love, involves satisfying various complicated reasons possession conditions. Whether to satisfy these conditions (e.g., to investigate certain facts, to develop certain know-how/competences) will often depend on the various interests or practical roles we adopt. ${ }^{28}$

depends, in part, on facts about the lover's qualities and desires-features that are more readily accessible to the lover. Note that even well-meaning friends who know you fairly well can still set you up on a disastrous date. Note also that even if love at first date is plausible, love at first friend recommendation is not. We trust but verify when it comes to love. Third, even granting that reliable testimony about another's loveable qualities can have the same justifying force as our own first-personal experience, note that determining who is a reliable source for such testimony could be even harder than in the case of morals and aesthetics.

26. This is not to say that there are never decisive reasons to engage in these kinds of interactions (even if one is in a relationship). This detail will be important in discussing how my view differs from Jollimore's (2011) Vision View.

27. Absent non-quality-based reasons based in relationships or commitments, it is difficult to come up with examples of reasons that would require us to attend to a person's qualities. First, there usually are not reasons of this sort that would require us to attend to specific intellectual, aesthetic, or physical pursuits. Second, even if there were such higher-order reasons, they probably will not affect what it is rational for us to do because we may simply fail to possess them. I should also note that what we attend to is not always subject to voluntary control. Nonetheless, the ways in which attention is influenced by and influences the reasons we possess should be the subject of future research. For examples of existing work, see Murdoch (1970) and Bommarito (2013) who leave an important role for attention in their accounts of virtue and moral motivation.

28. Buchak (2014) points out that evidence gathering is itself an activity that is governed by reasons. Also see Hunter (2018) who raises the question of knowledge directives (i.e., directives about what we ought to know). 


\subsubsection{Complexity and Commitment}

The Quality View is intuitively plausible. The qualities of a person are reasons to love them because they favor doing so. That said, Howard (2019) notes that there are other facts that can serve as legitimate reasons to love someone that aren't based in the qualities of the beloved. ${ }^{29}$ Such considerations includebut are not limited to - the value of a relationship, the value of romantically loving a person, and the existence of shared projects or children. I suspect that if we grant said considerations as legitimate reasons for love, this will help mitigate the Trading Up Problem for the rationalist lover. These reasons can combine with ordinary quality-based reasons to provide decisive reason to continue loving your beloved. ${ }^{30}$

But suppose our rationalist lover is a strict adherent of the Quality View. Suppose she denies that there are non-quality-based reasons that can justify love. Even if this is correct, note that there can be non-quality-based reasons to make sure that your quality-based reasons continue to favor loving your beloved. What I want to stress now is that these higher-order reasons also play a key role in maintaining the rationality of your romantic love.

For example, the value of your relationship with your beloved, the value of romantically loving them, and the value of your shared projects and children can provide higher-order reasons to make sure that your first-order quality-based reasons continue to decisively favor loving your beloved rather than others. In short, these facts provide us with reasons to fix our attention on our belovedsto spend time with them, to interpret their actions and attitudes charitably, and to forgo certain levels of intimacy with others.

The most important source of these reasons and a crucial component of the Possession-Commitment Account are the ones that we give ourselves-the commitments that we make to our beloveds. Consider marriage vows. One way of understanding what we are doing when we make such vows (though never quite stated this way) is that we are creating higher-order reasons to fix our attention on our beloveds so that we can continue to love them. By making these commitments, we give ourselves decisive reason to make it the case that we possess decisive quality-based reason to continue loving our beloveds.

Actual romantic practice confirms this diagnosis. If what it takes to possess the qualities of a person as reasons for love requires first-personal experience

29. See Kolodny (2003) for detailed discussion of how relationships play a role in the rationality of romantic love. Howard (2019) thinks that such reasons may simply be non-fit-based reasons for love. For additional discussion of non-fit based reasons for love, see Abramson and Leite (2011).

30. Granted, it could work the other way as well. Even if the person you love has great qualities, there might be other facts that count against continuing to love that person (e.g., you can't get along with them, your relationship with them has little value and brings disappointment to loved ones, etc.). 
or at least significant attention to discern what someone is actually like, then it is no wonder that in committing to our beloveds, we promise to lavish that time and prolonged attention on them and refrain from doing the same with other potential partners. This is not to say that we should never spend time with others. Marriage vows or other commitments we make to someone do not justify policies like refraining to eat meals with people who are not our beloveds. Instead, they justify the actual romantic practice of fostering prolonged and intimate first-personal experiences with our beloveds (e.g., private candle-lit dinners) while refraining from doing so with others. ${ }^{31}$

\subsection{Putting the Account to Use}

Having motivated the Possession-Commitment Account, let us see how the rationalist lover can address the Trading Up Problem while accounting for other features constitutive of ordinary romantic life.

\subsubsection{Love's Stability}

Romantic love tends to be rationally stable. When we love someone, we aren't required to love someone else when we notice that they have better qualities (trade up), stop loving our beloved when they lose their qualities (inconstancy), love everyone who has similar qualities as our beloved (promiscuity). Nor are others required to love our beloveds (universality). The Possession-Commitment Account can help us explain why this is so.

Though the rationalist lover cannot rule out the possibility that she ought to trade up in some cases, such cases would be rare. There are two reasons for this. First, we noted that possessing the qualities of a person as reasons to love them is more complicated than just knowing that they have those qualities. Tinder, even Super Tinder profiles, will not suffice for fully possessing a variety of personal qualities as reasons for love.

Second, recall Attention. The stability of your love will depend, in part, on how you direct your attention towards your beloved rather than towards others. This generates a plausible prediction: the extent to which you feel rational pressure to trade up will depend on (a) the reasons that you possess to focus your attention on your beloved and (b) the extent to which you are in control over the attention you pay to your beloved rather than others. For example, perhaps a high school senior from a small town is rationally required to trade up from her

31. Thanks to Sarah Stroud for pressing me on this point. 
bland girlfriend after meeting someone better at NYU. Note that the stability of one's love plausibly comes in degrees. Things are different if you are in a longterm committed relationship with someone and have decisive reason to attend to your beloved rather than others. On the other hand, if a lover is constantly forced to interact with potential romantic partners that are not her beloved or she has little self-control over whom she attends to, then it is plausible that her love life will be significantly less stable. Romantic love is somewhat messy after all.

We can address the inconstancy problem in two ways. First, even if a person loses their qualities, Complexity tells us there are non-quality-based reasons that may decisively favor loving your beloved. Defenders of the quality view who deny this could still accept that such non-quality-based facts function as higher-order reasons to focus your attention on your beloved to ensure that you continue to possess her qualities rather than the qualities of others as reasons to love them. In short, if our beloved loses some of their good qualities, we often possess decisive reason to keep looking for other good qualities in them. Second, whether your love is inconstant will again depend on how your attention is directed and whether you have reasons to direct your attention towards your beloved's qualities as opposed to others. The Possession-Commitment Account makes a plausible prediction. The extent to which your love is threatened by inconstancy depends on the strength of your higher-order reasons and your ability to resist temptations to avert your attention elsewhere.

As for the promiscuity problem, assuming the bar for possessing love's reasons can be quite high, whether you possess reasons to love multiple people will depend on what reasons you possess. If a lover spreads her attention across multiple people, and she has the resources to love multiple people, then perhaps she is rationally required to be promiscuous. For most of us, this will not apply if there are non-quality-based reasons that decisively favor loving our beloved or we simply do not have the kind of cognitive, affective, and physical resources of the promiscuous lover. A neat feature of the present account is that it allows for some individual variation. It leaves room for ethical polyamory (which will depend on the dispositions of individual lovers and the reasons they happen to possess) rather than taking its falsehood as a data point to be explained. ${ }^{32}$

32. A commentator noted that if you are a rationalist lover who also adheres to a strict quality view, you are committed to something very strange. If your beloved died but was replaced by a qualitative duplicate, then you are committed to loving that duplicate too. I do not think the rationalist lover has to adhere to the strict quality view, but it is not obvious the rationalist lover should not love the clone either. If psychological continuity is the correct account of personal identity, then you are just committing yourself to loving the same person. If not, the death of your actual beloved may give you decisive reason not to interact with her clone. If both your beloved and her clone exists at the same time, whether you possess most reason to love both persons will depend on the balance of possessed reasons in favor of or against being polyamorous. 
As for the universality problem, love rationalism supplemented with the Possession-Commitment Account does not entail that everyone is thereby required to love your beloved. Given Possession, if someone makes casual acquaintances with your beloved, they typically will not thereby possess most reason to love them. However, someone who has had intimate and prolonged interactions with your beloved may possess reasons that would require them to love your beloved. We cannot expect that an account of love will forbid others from loving our beloveds. That is something we have to take up with our beloveds and our romantic rivals. If, instead, the concern is that love cannot be required at all, let us turn to that now.

\subsubsection{Requirement and Options}

You might worry that for the rationalist lover, love will end up being rationally required in cases where you possess most reason to love someone. However, some think love can never be rationally required in this way. Though I believe this claim is false, the rationalist lover can nonetheless point out that she is seldom compelled by her possessed reasons to love a particular person.

Let us illustrate the point with a question. Does the rationalist lover always have to love the first person she meets with decent qualities? No. Recall our NYU freshman. Suppose she meets a decent person and begins to possess their qualities as reasons to love them. She is not thereby required to romantically love them supposing she has not met anyone else. This is because she has good reason to explore other options given her environment. Neither the PossessionCommitment Account nor Choice requires that romantic decisions (let alone decisions in general) must be based on time-slice judgments about the balance of reasons. Typically, deliberation is an extended process - insofar as deliberation about whom to love is possible, such deliberation is no different. ${ }^{33}$ Things change once non-quality-based reasons for love begin to accrue. When our NYU freshman becomes a senior with a loving fiancé with whom she has a valuable shared history and plans to have children, she will likely possess decisive reasons to love her fiancé or reasons to maintain that love.

I suspect that our resistance to the idea that love can be rationally required is that love always feels optional even if a potential beloved has great qualities. To make the optionality intuition stronger, let us imagine that the hypothetical lover who meets such a potential beloved is an unattached single person. Even so, we can account for the intuition of optionality in several ways without denying that love can be rationally required.

33. See Portmore (2011) for discussion of decision making and conceiving one's choices as a temporally extended process. 
First, we already noted that deciding whom to love is a temporally extended process and it can be rational to wait. Second, recall that recognizing that someone has great qualities does not mean that you thereby possess said qualities as reasons. Just meeting someone with great qualities does not entail that you must attend to them carefully. Third, though we can recognize that someone has great qualities, they need not be reasons for you to love them. Reasons for love are plausibly dependent, at least in part, on your qualities and interests too. As an academic, you can recognize that someone else is an excellent debater, but that might not be a reason for you to love that person. Perhaps the last thing you want after work is to come home to someone with stellar argumentative skills.

Furthermore, biting the bullet is not all that counterintuitive. If you (i) possess the qualities of a person as reasons to love them, (ii) correctly judge that you now have most reason to love them, and (iii) correctly judge that there aren't other people that you'll encounter with better qualities, then you may be rationally required to love such a person. I suspect that such cases are rather rare, but if these conditions are met, it is plausible that you are rationally required to love such a person. Failing to do so would be imprudent! Note also that even if it is odd to think that love can be rationally required, there are degrees of irrationality. Assuming the degree of irrationality is minimal, blame for imprudent management of one's romantic love may be comparably minimal when considering the appropriate blame for failing to execute a serious moral obligation instead.

Finally, claiming that love is always optional or voluntary ignores the fact that sometimes we do just fall in love. The rationalist lover can accommodate this phenomenon to some extent. Zangwill (2013) is right that love often seems to be caused in us rather than something we choose. We frequently fall in love rather than deliberate into love. In rare cases, love may even be possible at first sight. Or, more plausibly, they are instances that lead us to investigate a potential romantic partner further. Such cases may be perfectly rational even if they seem out of our control. This is because we may find ourselves in situations in which our attention is focused on the qualities of another or their qualities become especially salient to us (e.g., loneliness, going through an intense emotional or physical experience together etc.). In such cases, it is at least possible that we come to possess reasons for love that typically require continued interaction or much additional effort. Absent any reasons to hold out or wait for someone else, love at first sight may just be the result of the normal functioning of our subconscious and automatic capacities to possess and respond to reasons. 34

34. Admittedly, I am skeptical of "love at first sight" or "falling in love". My intention here is to explain how a rationalist lover could nonetheless claim that at least some cases of "love at first sight" or "falling in love" can be rational. In the cases I am envisioning, the lover is in a situation in which either the lover is abnormally open to a person's genuinely loveable qualities or the beloved's genuinely loveable qualities are abnormally on display. In such cases, 


\subsubsection{Love at its Worst}

The rationalist lover, as I have stipulated, will have to accept that when we possess most reason to love someone else, we are required to do so. I have argued that this is not as counterintuitive as we may have initially thought. I also want to point out that the rationalist lover also has something plausible to say in cases where love has gone horribly wrong.

Thus far, we have focused on cases in which a lover may already love someone that is decent but encounters someone with better qualities. However, we have not considered cases in which a lover is currently with someone who is horrible. Granted, our beloveds can come to lose their loveable qualities. But there are plenty of unfortunate cases in which beloveds not only lose their loveable qualities but also become abusive or lead us into harmful co-dependency. In the worst-case scenario, we may also have no reason to believe that our beloveds can change.

Though such cases require careful treatment that I cannot give here, the rationalist lover can make some plausible preliminary recommendations. First, even if a lover is clearly aware of the negative qualities of her beloved,

the rationalist could claim that it would be perfectly rational for a lover to quickly and non-reflectively come to love a beloved on the basis of possessing and responding to reasons (e.g., the beloved's genuinely loveable qualities). Note that this would simply be an instance of a general phenomenon: agents can engage in fully rational action or have fully rational attitudes on the basis of an immediate non-reflective response to genuine reasons. Think of the virtuous moral agent or even an agent highly skilled at a particular craft that non-reflectively acts in response to genuine reasons (e.g., a cellist, a basketball player, etc.). Nonetheless, I suspect that "love at first sight" is the exception rather than the norm. The rationalist lover can certainly accept (and should probably be inclined to say) that many cases of "love at first sight" or "falling in love" will not be rational. At least in the context of substantive rationality (i.e., possessing and responding to genuine reasons), the rationalist lover can say that such lovers are usually not loving rationally because they fail to fully possess genuine reasons for love. For example, such a lover could be mistaken about their beloved's qualities. Or as one reviewer points out, the lover may be blinded to reasons against love (e.g., the lover is unavailable, unsuitable, has many bad qualities, etc.).

Finally, note that the rationalist lover cannot be expected to propose a reflective decision procedure that would help a lover guarantee that her love is rational. Perhaps there are tests for structural rationality (i.e., that our mental states satisfy certain structural rationality constraints like means-ends coherence and non-contradiction), but there is no reflective decision procedure that would guarantee that we are generally substantively rational-much less for love specifically. Thus, I agree with the reviewer that if "love at first sight" or "falling in love" turns out to be rational, this may often depend on luck. I am no optimist. That said, a lover could skillfully place herself in a situation in which she is highly likely to meet people with great qualities or perhaps she is particularly good at discerning a person's qualities. If such a lover ends up "falling in love" with someone who genuinely has great qualities, then the substantive rationality of her love can be attributed to her skill as an experienced lover rather than to luck. 
she might not be able to thereby stop loving her beloved at will. ${ }^{35}$ Love can function like an addiction. ${ }^{36}$ Nonetheless, the rationalist lover can note that these negative qualities can serve as decisive reasons for the lover to physically and emotionally separate from her beloved or to sever her relationship with them. ${ }^{37}$ In virtue of engaging in these activities, the lover may, over time, no longer possess reasons to love her beloved and come to possess decisive reasons to love someone else instead. Second, note that a lover who faces an abusive or harmful beloved may be blinded to her beloved's negative qualities for a variety of reasons through no rational failure of her own. Such a lover may not be held at fault for continuing to love her beloved precisely because they are blind in this way. At this point, the rationalist lover can point out that even if such a lover may fail to possess reasons to leave her beloved or to stop loving them, supporters of the lover (e.g., friends, family, etc.) have a responsibility to help the lover possess such reasons. It is important for a lover's supporters to help them be aware of these reasons precisely because love's reasons have requiring rather than merely justifying strength as the rationalist lover insists.

If the Possession-Commitment Account is correct, then being a rationalist lover does not require us to be a romantic mess. In fact, it may actually help us get out of romantic messes.

\section{Elaborations}

I have drawn inspiration for the Possession-Commitment Account from recent discussions on love. It is worth noting how my account differs from these discussions. In addition, I will argue that even if perspectivism is false, the Possession-Commitment Account can nonetheless provide the rationalist lover with several resources to resist the Trading Up Problem.

35. A reviewer was worried that insofar as love is resistant to or not subject to voluntary control, it is unclear whether it can be rationally required. First, note that other forms of non-romantic love can be required even if not directly under our voluntary control. We may be required to continue loving a friend or our children even if we currently fail to do so. Second, note that other mental states can be rationally required even if they are not under our voluntary control. For example, belief may be rationally required in the face of compelling evidence even if we do not have voluntary control over our beliefs. This is not to say that such rational requirements hold regardless of our capacities.

36. See Brogaard (2014) for discussion on the biochemistry of romantic love.

37. Granted, there are important complications in these cases (e.g., a lover may unfortunately have a reason to stay with her abuser in order to protect their children or other dependents, the lover has made certain commitments to the beloved, etc.). 


\subsection{Naar on Irreplaceability and Fittingness}

Naar (in press) proposes that for us to fittingly love someone, we must bear a proper relation to their goodness: understanding. Furthermore, this understanding can only be achieved through first-personal connection. He writes: $3^{8}$
Formulated in terms of understanding, then, my claim is that the nature of the goodness of particular individuals is such that one can understand it (in a way that goes beyond what one knows) when one is suitably placed, and that this requires a first-personal connection with the rele- vant individuals that relationships can provide. When one has achieved the relevant sort of understanding with respect to the goodness of a particular individual, then one's normative situation is such that lov- ing them is fitting. Loving them would be fitting, furthermore, even if one knows that another individual has similar qualities and is thereby equally lovable.

I agree with Naar that first-personal experience plays a crucial role in accounting for the rationality of love and that something like understanding as opposed to mere knowledge of a person's goodness is what makes it fitting or rational to love that person. The Possession-Commitment Account provides the metaethical tools to explain why first-personal experience can play this role.

On the present proposal, first-personal experience of a person's qualities (what constitutes understanding for Naar) is often what allows us to possess those qualities as reasons for love. Since what attitudes we ought to have is a function of the reasons we possess and first-personal experience is what explains how we possess the qualities of our beloveds rather than the qualities of strangers as reasons for love, the presence or absence of first-personal experience helps determine when we ought to love someone. This is how first-personal experience (or understanding) of a person can, as Naar rightly notes, make it so that one's situation is such that loving them is fitting.

An additional difference is my emphasis on commitment and the active role a lover plays in maintaining her love for her beloved. By continuing to attend to our beloved's qualities while refraining from lavishing the same attention on others, we take active steps to possess decisive reason to love our beloveds. Since Naar primarily focuses on the role first-personal experience plays in justifying

38. The passage is quoted from page 26 of the pdf downloaded from the online published version of Naar (in press). Use https://link.springer.com/content/pdf/10.1007/s11229-018-02079-4. pdf to access the paper. 
love, he leaves the rationalist lover with fewer resources to address the Trading Up Problem.

\subsection{Jollimore on Love's Vision}

My emphasis on the lover's attention to her beloved's qualities is inspired by Jollimore. On his Vision View, loving someone is a matter of freely attending to their qualities as opposed to others. Jollimore is right that a key feature of romantic love involves a generous and continued attention to the beloved. ${ }^{39}$ Nonetheless, there are important differences between our views worth mentioning.

First, the Vision View appeals to non-requiring reasons (i.e., reasons that favor actions and attitudes without playing any role in generating deontic or rational verdicts), while the Possession-Commitment Account does not. ${ }^{4^{\circ}} \mathrm{My}$ view is consistent with the claim that all reasons can contribute to explanations of rational requirements or obligations.

Second, appealing to reasons possession provides a simple way of understanding the normative significance of attention. On the Vision View, when we attend to the qualities of our beloved as opposed to others, the qualities of others become silenced as reasons for love even though we recognize them as genuine qualities. Possession can explain how this occurs. When we attend to a person's qualities carefully, we increase the likelihood of knowing how said qualities favor loving them. When we do not attend to a person's qualities this way, we either do not possess their qualities as reasons or only do so to a limited degree (plausibly decreasing their weight in our deliberation). Qualities

39. A historical precursor to both our views is arguably Augustine's view on which love is the overall direction of the will towards a particular object. See Augustine (2004) De civitate dei 14.7.

40. See Jollimore (2011: 71-72). There are two reasons for why one might object to positing such reasons. First, Munoz (2018) has pointed out that the distinction between requiring and non-requiring reasons is extremely hard to draw. He writes (referring to the distinction as the moral/non-moral distinction):

Any line we draw around the moral will need to rule in the classic mandatory benefits to others, along with the intuitive duties to take minimal care of oneself, while somehow excluding the benefits of flossing one's own teeth and doing nice favors for other people. This is not an easy line to draw; these benefits do not seem so intrinsically different (draft: 7).

Second, Robertson (2008) has pointed out that non-requiring reasons are supposed to never play a role in determining deontic verdicts. But they intuitively can once we combine them with other non-requiring reasons. For example, the fact that some option is pleasurable may be a non-requiring reason that, on its own, may not require you to take it. However, add enough of these reasons and it will eventually be the case that these reasons would require you to choose the option on prudential grounds. 
are 'silenced' in virtue of our not paying attention to them in ways that would lead us to possess them fully as reasons for love.

Third, unlike the Vision View, the Possession-Commitment Account grants that attention is itself reason-governed. There can be reasons for diverting our attention away from our beloved or reasons to also focus on their negative qualities. In cases of abuse or co-dependency in which lovers can be unwillingly blinded to their beloved's negative qualities or harmful behaviors, there are reasons that govern how the abused should attend to their lover even if they fail to possess them. Supporters can help victims possess these reasons. On the flipside, only focusing on a beloved's positive qualities may also inhibit their personal growth or hold them up to a damaging ideal. Lastly, there can also be reasons for keeping our attention focused on our beloved. Some non-quality-based reasons plausibly function as higher-order reasons to manage your first order (quality-based) reasons to love your beloved. As we noted, marriage vows work by generating reasons to focus our attention on our spouses rather than on others. ${ }^{41}$

\subsection{Perspectivism}

Finally, Rationality and Possession assume a version of perspectivism. What you ought to do depends on your possessed reasons which, in turn, depends on your epistemic perspective and practical competences.

Suppose you rejected this claim in favor of objectivism about ought judgments. Perhaps what it is rational to do is dependent on your perspective, but what you ought to do is fully determined by objective reasons (regardless of whether you are aware of them). On this view, if there is some person(s) such that the objective reasons most support loving her/them, then you ought to do so even if you do not know of their qualities or even their existence. Would this pose intractable problems for the Possession-Commitment Account's way of accommodating normal romantic life?

First, most objectivists would want to divorce ought judgments from praise and blame judgments. If so, then even if it is true in some objective sense that you ought to trade up (suppose that there is someone so great that their qualities outweigh all the reasons there are to love your own beloved), one can't be blamed for not doing so. Blame depends on rationality which is a function of possessed

41. Commitments such as marriage vows can also help us understand how we can love on the basis of qualities without making love conditional on them. Love is importantly quality based. As Delaney (1996) points out, we cannot love a person abstractly (i.e., we cannot love their haecceity/non-qualitative thisness). Nonetheless, we love our beloveds not just for their present set of qualities qua Humean bundle. Instead, marriage vows are commitments to continue to seek and appreciate the qualities of our beloveds even as they change over time. 
reasons. Second, I suspect that if the objectivist wants to avoid the strange result that one ought to love a stranger, then she will want to appeal to certain relational facts (e.g., enjoy each other's company, are good friends, share interests and projects, etc.) or prudential facts (e.g., loving someone you know is more rewarding than loving someone who has no idea who you are or does not love you back, etc.) that would outweigh the quality-based reasons to love some fantastic unknown beloved. But if this is so, then agents will retain significant control over whom they ought to love in virtue of their control over whether such relational and prudential facts obtain. This keeps the spirit of the Possession-Commitment Account and still goes a significant way in satisfying the desiderata. Thus, objectivism about ought judgments, even if true, would pose no in-principle problem for love rationalism when combined with the Possession-Commitment Account.

\section{Conclusion}

In this paper, I've argued that the rationalist lover (i.e., someone who accepts the plausible claims that (i) we ought to do (feel) what we have most reason to do (feel) and (ii) the qualities of a beloved are weighty reasons to romantically love them) can lead a normal romantic life. By proposing the PossessionCommitment Account, we've noted that the rationalist lover can have a normal romantic life once we think more carefully about (i) how we come to possess reasons for love and (ii) the higher-order reasons that govern whether we should seek or refrain from possessing further reasons for love.

Let us close with three reasons for why we should care about this result. First, the rationalist lover is not some bizarre philosophical figure. She is just a practically rational agent that makes no exceptions in the case of love and has a plausible view about what counts as a reason for love. Good news for the rationalist lover means we have reason to believe that being practically rational will not drastically conflict with how we lead our romantic lives either. Second, the present proposal is both systematic and philosophically conservative. We have made no use of any special kinds of reasons (e.g., second-personal, haecceistic, non-insistent reasons, etc.) and we relied on an ecumenical account of romantic love. The only tools we needed were an account of reasons possession that is well-motivated and the uncontroversial claim that we sometimes have higher-order reasons to initiate or refrain from searching for more reasons. Lastly, note the solution presented here may be extended to other areas of our practical lives. Just as we can resist the rational pressure to trade up in our romantic lives, we may appeal to similar considerations to resist the rational pressure to trade up in regard to other important personal projects such as our vocations and plans. In sum, life is messy but at least we can be rational about it. 


\section{Acknowledgments}

I would like to thank Meghan Sullivan, Kieran Setiya, Laura Callahan, and anonymous reviewers for their invaluable feedback on multiple versions of this paper. I would also like to thank members of the Chapel Hill Normativity Conference 2018, the Notre Dame Dissertation Reading Group 2019, and the students in my Fall 2019 course on love and friendship at Notre Dame. Finally, thanks to all those whose love has kept me going in this profession. In particular, thanks to my parents whose love for one another and for me has been an inspiration for this project.

\section{References}

Abramson, Kate and Adam Leite (2011). Love as a Reactive Emotion. The Philosophical Quarterly, 61(245), 673-99.

Augustine of Hippo (2004). City of God. Henry Bettenson (Ed. and Trans.). Penguin.

Buchak, Lara (2014). Rational Faith and Justified Belief. In Laura F. Callahan and Timothy O'Connor (Eds.), Religious Faith and Intellectual Virtue (49-73). Oxford University Press. Bommarito, Nicolas (2013). Modesty as a Virtue of Attention. Philosophical Review, 122(1), 93-117.

Brogaard, Berit (2014). On Romantic Love: Simple Truths about a Complex Emotion. Oxford University Press.

Dancy, Jonathan (2004). Enticing Reasons. In R. Jay Wallace, Phillip Pettit, Samuel Scheffler, and Michael Smith (Eds.), Reason and Value: Themes from the Moral Philosophy of Joseph Raz (91-118). Oxford University Press.

Delaney, Neil (1996). Romantic Love and Loving Commitment: Articulating a Modern Ideal. Philosophical Quarterly, 33(4), 339-56.

De Sousa, Ronald (2015). Love: A Very Short Introduction. Oxford University Press.

Dillon, Robin (1997). Self Respect: Moral, Emotional, Political. Ethics, 107(2), 226-49.

Ebels-Duggan, Kyla (2019). Beyond Words: Inarticulable Reasons and Reasonable Commitments. Philosophy and Phenomenological Research, 98(3), 623-41.

Faraci, David (2020). We Have No Reason to Think There Are No Reasons for Affective Attitudes. Mind, 129(513), 225-34.

Fox, Philip (2019). Revisiting the Argument from Action Guidance. Journal of Ethics and Social Philosophy, 15(3), 222-54.

Frankfurt, Harry G. (2004). The Reasons of Love. Princeton University Press.

Gert, Joshua (2003). Requiring and Justifying: Two Dimensions of Normative Strength. Erkenntnis, 59(1), 5-36.

Han, Yongming (in press). Do We Love For Reasons? Philosophy and Phenomenological Research.

Howard, Chris (2019). Fitting Love and Reasons for Loving. In Mark Timmons (Ed.), Oxford Studies in Normative Ethics (Vol. 9, 116-37). Oxford University Press.

Hunter, David (2018). Directives for Knowledge and Belief. In Conor McHugh, Jonathan Way, and Daniel Whiting (Eds.), Normativity: Epistemic and Practical (68-89). Oxford University Press. 
Jenkins, Carrie (2017). What Love Is: And What It Could Be. Basic Books.

Jollimore, Troy (2011). Love's Vision. Princeton University Press.

Kiesewetter, Benjamin (2011). 'Ought' and the Perspective of the Agent. Journal of Ethics and Social Philosophy, 5(3), 1-24.

Kiesewetter, Benjamin (2018). How Reasons are Sensitive to Available Evidence. In Conor McHugh, Jonathan Way and Daniel Whiting (Eds.), Normativity: Epistemic and Practical (90-114). Oxford University Press.

Kolodny, Niko. (2003) Love as Valuing a Relationship. Philosophical Review, 112(2), 135-89.

Little, Margaret and McNamara, Colleen (2017). For Better or Worse: Commendatory Reasons and Latitude. In Mark Timmons (Ed.), Oxford Studies in Normative Ethics (Vol. 7, 138-60). Oxford University Press.

Lord, Errol (2018a). How to Learn about Aesthetics and Morality Through Acquaintance and Testimony. In Russ Shafer-Landau (Ed.), Oxford Studies in Metaethics (Vol. 13, 71-97). Oxford University Press.

Lord, Errol (2018b). The Importance of Being Rational. Oxford University Press.

Maguire, Barry (2018). There Are No Reasons for Affective Attitudes. Mind, 127(507), 779-805.

Martin, Adrienne (2014). How We Hope: A Moral Psychology. Princeton University Press.

Munoz, Daniel (2018). All Reasons Are Moral. Unpublished manuscript.

Murdoch, Iris (1970). The Sovereignty of Good. Routledge.

Naar, Hichem (2017). Subject-Relative Reasons for Love. Ratio, 30(2), 197-214.

Naar, Hichem (in press). The Possibility of Fitting Love: Irreplaceability and Selectivity. Synthese.

Parfit, Derek (2011). On What Matters (Vol. 1). Oxford University Press.

Portmore, Douglas (2011). Commonsense Consequentialism: Wherein Morality Meets Rationality. Oxford University Press.

Robertson, Simon (2008). Not So Enticing Reasons. Ethical Theory and Moral Practice, $11(3), 263-77$.

Schroeder, Mark (2008). Having Reasons. Philosophical Studies, 139(1), 57-71.

Setiya, Kieran (2014). Love and the Value of a Life. Philosophical Review, 123(3), 251-80.

Setiya, Kieran (2016). Retrospection. Philosopher's Imprint, 16(15), 1-15.

Setiya, Kieran (in press). Other People. In Nandi Theunissen and Sarah Buss (Eds.), The Value of Humanity. Oxford University Press.

Solomon, Robert (2006). About Love: Reinventing Romance for Our Times. Hackett.

Velleman, David (1999). Love as a Moral Emotion. Ethics, 109(2), 338-74.

Whiting, Daniel (2015). The Glass is Half Empty: A New Argument for Pessimism about Aesthetic Testimony. British Journal of Aesthetics, 55(1), 91-107.

Wodak, Daniel (in press). Approving on the Basis of Normative Testimony. In Russ Shafer-Landau (Ed.), Oxford Studies in Metaethics (Vol. 16). Oxford University Press.

Zangwill, Nick (2013). Love: Gloriously Amoral and Arational. Philosophical Explorations, 16(3), 298-314. 